\title{
A Survey of Public Knowledge and Attitude Related to Antibiotic use and Antibiotic Resistance among Saudi People in Northern Region of Saudi Arabia
}

\author{
Abdullah Ajab Hjaj Alenazi, Nawaf Mohamed Alotaibi, Md Ali Mujtaba* \\ Department of Pharmaceutics, Faculty of Pharmacy, Northern Border University, KINGDOM OF SAUDI ARABIA.
}

\begin{abstract}
Background: The antibacterial resistance is emerging problem worldwide. This phenomenon is nowadays affecting public health dramatically on the global level. Public knowledge is considered a prerequisite for appropriate use of antibiotics and limited spread of antibiotic resistance. Our aim was to evaluate the level of knowledge, beliefs, attitude and behaviors toward antibiotic resistance among Saudi public in northern border region of Saudi Arabia. Methods: A cross-sectional study was conducted in northern border region of Saudi Arabia using a self-administeredquestionnaire in Arabic language and all data were analyzed by means of descriptive analysis. Results: More than two thirds of study subjects reported that they heard about antibiotic resistance and $35 \%$ of them mentioned the social media as the source of information about this issue, only $44 \%$ of study subjects were aware that antibiotic resistance means that bacteria would not be killed by antibiotic, $42 \%$ were aware that antibiotic resistance bacteria is difficult to eradicate, $58 \%$ were aware that indiscriminate use of antibiotics is the cause of bacterial resistance, $34 \%$ were aware that use antibiotic when there is no need is a cause for bacterial resistance, $38 \%$ were aware that incomplete course of antibiotic lead to bacterial resistance, $43 \%$ of
\end{abstract}

study subjects take antibiotic without prescription, $42 \%$ stop antibiotic when symptoms improve and $47 \%$ of study subjects believed that influenza and common cold can be treated with antibiotics. Conclusion: Our community still has some misconception and insufficient knowledge regarding antibiotic resistance. There is great concern surrounding the development and spread of resistance resulting from poor knowledge about the dangers of self-medication and misuse of antibiotics.

Key words: Knowledge, Attitude, Antibiotics, Saudi Arabia, Antibiotic resistance.

Correspondence

Dr. Md Ali Mujtaba,

Assistant Professor, Department of Pharmaceutics, Faculty of Pharmacy, Northern Border University, Rafha-91911, KINGDOM OF SAUDI ARABIA.

Phone: +91-9891611864

Email: sajanqa@gmail.com

DOI: 10.5530/jyp.2020.12.67

\section{INTRODUCTION}

The antibacterial resistance is an emerging problem worldwide. This phenomenon is nowadays affecting public health dramatically on the global level. It is estimated that at least every $10 \mathrm{~min}$ a patient die in the USA or Europe because of fatal infectious diseases caused by antibiotic resistant bacteria. ${ }^{1}$ Unfortunately, the current dependence on antibiotics either for treatment or prevention led to increase in resistance. Overuse of antibiotics lead to selective pressure forcing the bacteria to mutate or acquire some traits to help them in sustaining the pressures and to become resistant. ${ }^{2}$ Indiscriminate use and misuse of antibiotics lead to antimicrobial resistance (AMR) due to selection pressure faced by bacteria. $^{3}$ Despite this known fact, approximately 10 million tons of antibiotics are globally used every ten minutes, which are mostly not related to justified medical use. ${ }^{4}$ As a result of the AMR all over the world, common infections, such as urinary tract infections are becoming difficult to treat. This is mainly due to bacteria that are resistant to last line antibiotics or even pan-drug resistant those are not responding to any currently commercial available antibiotics. ${ }^{2,5}$ The multidrug resistant (MDR) pathogens are spreading rapidly in many parts of the world causing severe medical and economic consequences.

Resistance to antibiotics can occur anywhere in the world and it is considered a serious global health problem. Antibiotic resistance could greatly affect a country and could affect people of any age, leading to increasing costs and length of stay in the hospital. The WHO has made the problem of solving antibiotic resistance one of its priorities. The WHO introduced a global campaign to increase the awareness of the public towards antibiotic resistance and also to encourage the public to make appropriate use of antibiotics. ${ }^{6}$ To initiate any sort of effective intervention, it is necessary to attain an understanding of the public beliefs, knowledge and behavior pertaining to the use of antibiotics. Several well-documented studies have been conducted to do just that. ${ }^{7}$ ${ }^{9}$ Such studies focused on assessing the use of antibiotics in general or for specific diseases like upper respiratory tract infections (URTIs). The knowledge, beliefs and behavior of the public or patients are multifactorial and differ depending on the population or region. There are only limited number of published studies in Saudi Arabia assessing medication compliance by patients as well as the public's knowledge and belief toward drug use, including antibiotics use and resistance.

The public plays a significant role with regard to reducing the misuse of antibiotics and their excessive use. Therefore, it is necessary to assess the level of knowledge and attitude of the public towards the use of antibiotics in order to find out what education the public may need. ${ }^{10}$ Hence the aim of our study was to evaluate the knowledge and beliefs of Saudi in the northern border region of Saudi Arabia toward antibiotics resistance and to evaluate attitudes and behaviors toward antibiotic use and antibacterial resistance.

This is an open access article distributed under the terms of the Creative Commons Attribution-NonCommercial-ShareAlike 4.0 License, which allows others to remix, tweak, and build upon the work non-commercially, as long as the author is credited and the new creations are licensed under the identical terms. 


\section{MATERIALS AND METHODS}

This cross-sectional study was conducted during a period of three months from November 2018 to January 2019 in northern border region of Saudi Arabia using a validated questionnaire. The questionnaire was distributed online to a random sample of the people living in different regions of northern border region of Saudi Arabia. The questionnaire was divided into four main sections and consisted of 28 questions. The first part of the questionnaire was related to Socio-demographic data such as age, sex, education, nationality and marital status. The second section was composed of questions, which assessed knowledge and beliefs about antibiotic resistance in general. The third section regarding behaviors of antibiotic use and finally fourth section that showed attitude toward antibiotic use and antibacterial resistance among Saudi people of northern region. The Inclusion criteria for this study were Saudi males and females above the age of 16 years, agree to participate in the study and not work in health sector. The questionnaire was tested for its readability and understanding to the public before distribution. All participants were asked to answer all questions and incomplete questionnaires were omitted from the study. All data were analyzed by using SPSS version 20(IBM, Chicago, IL). The suggestive analysis was used to pick the demographic information in rates and percentages. The variations between the two groups are compared with the use of the chisquare test. A $p$-value of $<0.05$ was considered statistically significant.

\section{RESULTS}

The number of respondents included in the survey was 1095, with the majority, $64 \%$ being female. The socio-demographic characteristics of the respondents are presented in Table 1 . The largest percentage of the participants (32\%) was in the age range of $25-34$ years and $27 \%$ in the age range of 16-24 years. Most of the participants were university graduates (43\%) and married (57\%).

The knowledge and beliefs of antibiotics resistance on the part of the study participant was elicited by using twelve statements (Table 2). The majority of the participants (67\%) heard about antibiotic resistance and $35 \%$ of them mentioned the social media as the source of information about this issue while $17 \%$ mentioned the pharmacist as the source of information $(p<0.05)$. Only $44 \%(p<0.05)$ of study subjects were aware that antibiotic resistance means that bacteria would not be killed by the antibiotics, $42 \%(p<0.05)$ were aware that antibiotic resistance bacteria is difficult to eradicate, $58 \%(p<0.05)$ were aware that indiscriminate use of antibiotics is the cause of bacterial resistance, 34\% $(p=0.009)$ were aware that use antibiotic when there is no need is a cause for bacterial resistance, $38 \%(p=0.048)$ were aware that incomplete course of antibiotic lead to bacterial resistance, 53\% $(p<0.05)$ were aware that overuse of antibacterial lead to bacterial resistance, $44 \%(p<0.05)$ believed that longer duration of antibiotic increase bacterial resistance, $41 \%(p<0.05)$ were aware that resistant bacteria can be transmitted from patient to another, $51 \%(p<0.05)$ believed that antibiotic resistance occurs due to resistance in the body not the bacteria, 30\% believed that antibiotic can be stopped when the patient feel better.

Figure 1 represents the behavior of study subjects towards antibiotics use. A large percentage (43\%) of study subjects take antibiotic without prescription, 63\% reported taking antibiotic according to instructions, $42 \%$ stop antibiotic when symptoms improve, 39\% reported taking advise about antibiotic from pharmacist in private pharmacy.

Attitudes of participant towards antibiotic use and antibacterial resistance are presented in Table 3. Large percentage $(47 \%$; $p<0.05)$ of study subjects believed that influenza and common cold can be treated with antibiotics, $48 \%(p<0.05)$ believed that antibiotic resistance is a problem can affect them or their family, $44 \%(p<0.05)$ believed that wrong concept of antibiotic resistance is not present here but present in other countries, $48 \%(p<0.05)$ believed that that antibacterial resistance is a worldwide problem, 39\% $(p<0.05)$ believed that antibacterial resistance is only problem for people who regularly take antibiotics and $56 \%(p<0.05)$ believed that health care workers can help in limiting bacterial resistance.

\section{DISCUSSION}

The present study conducted with the aim to assess knowledge, belief, attitude and behavior of Saudi population towards overuse of antibiotics and antibiotic resistance in northern border region in Saudi Arabia. Less than half of the study participants $(48 \%$; $p<0.05)$ were aware that antibacterial resistance is a worldwide problem and also less than half $(48 \% ; p<0.05)$ were aware that antibiotic resistance is a problem that can affect them or their families. This result is similar to previous studies where most of the participants did not give importance to the prevalence of the antibiotic resistance. ${ }^{11,12}$ The insufficient awareness about the antimicrobial resistance indicates the need for education interventions using clinical problems which depicts the hazardous effects of antibiotic resistance, can be used to improve as well as make them alert on present and future consequences, which encourages the correct usage of antibiotics by avoiding the resistance which increased all over the world. ${ }^{13}$

There are some wrong beliefs noticed in the attitude of the respondents lead to inappropriate use of antibiotic. $42 \%(p<0.05)$ of study subjects believe that antibiotic can be stopped when symptoms improve. Similar reports were seen in another study. ${ }^{14}$ Almost, $47 \%(p<0.05)$ of study subjects believed that antibiotics can be taken for common cold and influenza and which is much higher than reported in previous study by Afzal et al. 2013(22.7\% were not aware that cold and flu not bacterial diseases).${ }^{15}$ However this result is less that reported in previous studies have shown that about $60 \%$ and more of their participants believed that antibiotics should be prescribed during cold of viral etiology ${ }^{16}$ such wrong and mistaken beliefs may lead to indiscriminate use of antibiotic resulting in increased bacterial resistance. ${ }^{17}$ Antibiotic treatment is not necessary in otherwise healthy young adults with common cold because common cold is a viral infection and bacterial co-infection are rare. ${ }^{18}$

Table 1: Demographic characteristics of study subjects $(n=1095)$.

\begin{tabular}{cccc}
\hline Variable & Categories & Frequency $(\mathbf{n})$ & Percentage (\%) \\
\hline Sex & Male & 398 & $36 \%$ \\
Age & Female & 697 & $64 \%$ \\
& $16-24$ years & 291 & $27 \%$ \\
& $25-34$ years & 355 & $32 \%$ \\
& $35-44$ years & 249 & $23 \%$ \\
& $45-54$ years & 118 & $11 \%$ \\
& $55-64$ years & 68 & $6 \%$ \\
Education & Secondary education & 271 & $1 \%$ \\
& Diploma & 219 & $25 \%$ \\
& University education & 473 & $20 \%$ \\
& Master & 63 & $43 \%$ \\
& Doctorate & 17 & $6 \%$ \\
& Married & 629 & $2 \%$ \\
& Not married & 466 & $57 \%$ \\
\hline
\end{tabular}


Table 2: Knowledge and beliefs of study subjects about antibiotic resistance. ( $n=1095)$.

\begin{tabular}{|c|c|c|c|c|}
\hline Statement & Categories & Frequency & Percentage & ${ }^{*} p$-Value \\
\hline \multirow{2}{*}{$\begin{array}{l}\text { Have you ever heard about } \\
\text { antibiotic resistance? }\end{array}$} & Yes & 730 & $67 \%$ & \multirow[t]{2}{*}{$<0.05$} \\
\hline & No & 365 & $33 \%$ & \\
\hline \multirow[t]{4}{*}{$\begin{array}{l}\text { Your source of information about } \\
\text { antibiotic resistance }\end{array}$} & $\begin{array}{l}\text { Social media/ } \\
\text { media }\end{array}$ & 385 & $35 \%$ & \multirow[t]{4}{*}{$<0.05$} \\
\hline & Friends/ relatives & 161 & $15 \%$ & \\
\hline & Pharmacist & 187 & $17 \%$ & \\
\hline & Physician & 180 & $16 \%$ & \\
\hline \multirow{3}{*}{$\begin{array}{l}\text { Antibiotic resistance means that } \\
\text { bacteria would not be killed by } \\
\text { antibiotic }\end{array}$} & Yes & 484 & $44 \%$ & \multirow[t]{3}{*}{$<0.05$} \\
\hline & No & 285 & $26 \%$ & \\
\hline & Don’t know & 326 & $30 \%$ & \\
\hline \multirow{3}{*}{$\begin{array}{l}\text { Antibiotic resistance bacteria is } \\
\text { difficult to eradicate }\end{array}$} & Yes & 460 & $42 \%$ & \multirow[t]{3}{*}{$<0.05$} \\
\hline & No & 326 & $30 \%$ & \\
\hline & Don’t know & 309 & $28 \%$ & \\
\hline \multirow{3}{*}{$\begin{array}{l}\text { Indiscriminate use of antibiotics is } \\
\text { the cause of bacterial resistance }\end{array}$} & Yes & 639 & $58 \%$ & \multirow[t]{3}{*}{$<0.05$} \\
\hline & No & 232 & $21 \%$ & \\
\hline & Don’t know & 224 & $20 \%$ & \\
\hline \multirow{3}{*}{$\begin{array}{l}\text { Use antibiotic when there is } \\
\text { no need is a cause for bacterial } \\
\text { resistance }\end{array}$} & Yes & 373 & $34 \%$ & \multirow[t]{3}{*}{0.009} \\
\hline & No & 411 & $37 \%$ & \\
\hline & Don’t know & 311 & $29 \%$ & \\
\hline \multirow{3}{*}{$\begin{array}{l}\text { Incomplete course of antibiotic } \\
\text { lead to bacterial resistance }\end{array}$} & Yes & 411 & $38 \%$ & \multirow[t]{3}{*}{0.048} \\
\hline & No & 361 & $29 \%$ & \\
\hline & Don’t know & 323 & $33 \%$ & \\
\hline \multirow{3}{*}{$\begin{array}{l}\text { Overuse of antibacterial lead to } \\
\text { bacterial resistance }\end{array}$} & Yes & 577 & $53 \%$ & \multirow[t]{3}{*}{$<0.05$} \\
\hline & No & 266 & $24 \%$ & \\
\hline & Don’t know & 252 & $23 \%$ & \\
\hline \multirow{3}{*}{$\begin{array}{l}\text { Longer duration of antibiotic } \\
\text { increase bacterial resistance }\end{array}$} & Yes & 482 & $44 \%$ & \multirow[t]{3}{*}{$<0.05$} \\
\hline & No & 291 & $27 \%$ & \\
\hline & Don’t know & 322 & $29 \%$ & \\
\hline \multirow{3}{*}{$\begin{array}{l}\text { Resistant bacteria can be } \\
\text { transmitted form patient to } \\
\text { another }\end{array}$} & Yes & 454 & $41 \%$ & \multirow[t]{3}{*}{$<0.05$} \\
\hline & No & 309 & $28 \%$ & \\
\hline & Don’t know & 323 & $30 \%$ & \\
\hline \multirow{3}{*}{$\begin{array}{l}\text { Antibiotic resistance occur due } \\
\text { to resistance in the body not the } \\
\text { bacteria }\end{array}$} & Yes & 558 & $51 \%$ & \multirow[t]{6}{*}{$<0.05$} \\
\hline & No & 233 & $21 \%$ & \\
\hline & Don't know & 304 & $28 \%$ & \\
\hline \multirow[t]{3}{*}{$\begin{array}{l}\text { In your opinion, antibiotic can be } \\
\text { stopped }\end{array}$} & $\begin{array}{l}\text { After completing } \\
\text { the course }\end{array}$ & 561 & $51 \%$ & \\
\hline & $\begin{array}{l}\text { When the patient } \\
\text { feel better }\end{array}$ & 331 & $30 \%$ & \\
\hline & I don’t know & 203 & $18 \%$ & \\
\hline
\end{tabular}

${ }^{*} p$-Value Calculated with chi-square test.

${ }^{*} p$-value $0 \leq 0.05$ consider as significant.

The results of the present study indicate that participants lack sufficient awareness about the bacterial resistance. Less than half $(44 \%$; $p<0.05)$ of the participants were aware that antibiotic resistance means that bacteria would not be killed by antibiotic. The present study showed that (43\%; $p<0.05)$ of participants take antibiotics without prescription which is similar to another study performed in Saudi Arabia which confirmed that $48 \%$ of participants reported using antibiotics without consulting a physician. ${ }^{19}$ An addition, reports from neighboring countries including Iraq, Egypt, Jordan and Palestine as well as other parts of the globe showed the imprudent, overuse and self-medication with antibiotics. ${ }^{20-24}$ Although $(38 \% ; p<0.05)$ of participants were aware that incomplete course of antibiotic lead to bacterial resistance, a large percentage of our study subjects $(42 \% ; p<0.05)$ reported that they would stop antibiotic when symptoms improve. Comparing our results with the previous 
Table 3: Attitudes of study subjects regarding antibiotic use and antibacterial resistance ( $n=1095)$.

\begin{tabular}{|c|c|c|c|c|}
\hline Statement & Categories & Frequency & Percentage & ${ }^{*} p$-Value \\
\hline \multirow{3}{*}{$\begin{array}{l}\text { Influenza and common cold can be } \\
\text { treated with antibiotics }\end{array}$} & Yes & 518 & $47 \%$ & \multirow[t]{3}{*}{$<0.05$} \\
\hline & No & 341 & $31 \%$ & \\
\hline & Don't know & 236 & $22 \%$ & \\
\hline \multirow{3}{*}{$\begin{array}{l}\text { Antibiotic resistance is a problem can } \\
\text { affect me or my family }\end{array}$} & Yes & 530 & $48 \%$ & \multirow[t]{3}{*}{$<0.05$} \\
\hline & No & 246 & $22 \%$ & \\
\hline & Don't know & 319 & $29 \%$ & \\
\hline \multirow{3}{*}{$\begin{array}{l}\text { Wrong concept of antibiotic resistance } \\
\text { is not present here but present in other } \\
\text { countries }\end{array}$} & Yes & 487 & $44 \%$ & \multirow[t]{3}{*}{$<0.05$} \\
\hline & No & 269 & $25 \%$ & \\
\hline & Don't know & 339 & $31 \%$ & \\
\hline \multirow{3}{*}{$\begin{array}{c}\text { Antibacterial resistance is a worldwide } \\
\text { problem }\end{array}$} & Yes & 523 & $48 \%$ & \multirow[t]{3}{*}{$<0.05$} \\
\hline & No & 235 & $21 \%$ & \\
\hline & Don't know & 337 & $31 \%$ & \\
\hline \multirow{3}{*}{$\begin{array}{l}\text { Antibacterial resistance is only problem } \\
\text { for people who regularly take antibiotics }\end{array}$} & Yes & 432 & $39 \%$ & \multirow[t]{3}{*}{$<0.05$} \\
\hline & No & 327 & $30 \%$ & \\
\hline & Don't know & 336 & $31 \%$ & \\
\hline \multirow{3}{*}{$\begin{array}{l}\text { Health care workers can help in limiting } \\
\text { bacterial resistance }\end{array}$} & Yes & 614 & $56 \%$ & \multirow[t]{3}{*}{$<0.05$} \\
\hline & No & 218 & $20 \%$ & \\
\hline & Don't know & 263 & $24 \%$ & \\
\hline
\end{tabular}

${ }^{*} p$-Value Calculated with chi-square test.

${ }^{*} p$-value $0 \leq 0.05$ consider as significant.

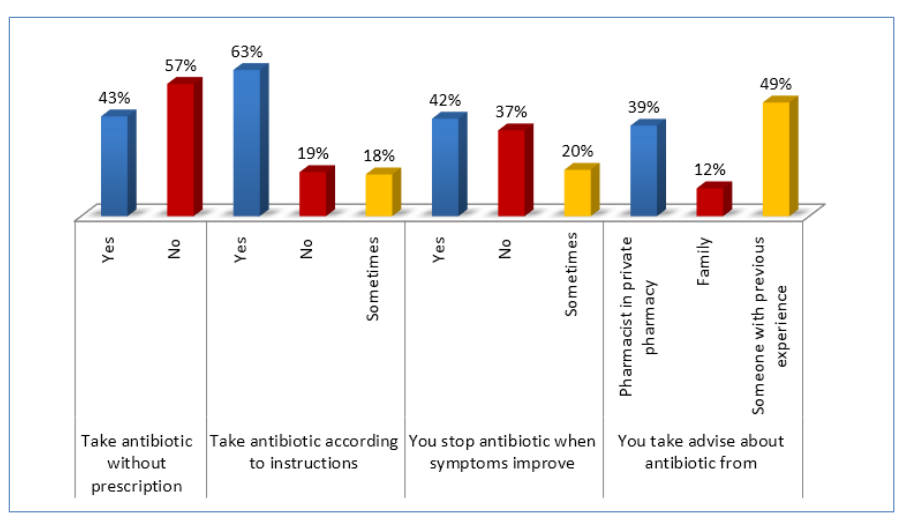

Figure 1: Behaviors of study subjects toward antibiotic use.

study of Belkina et al. 2014 showed that $38.8 \%$ of the respondents stop taking antibiotic if they feel bettershowing that we have a worse result this means that most of the respondents have insufficient awareness in this issue. ${ }^{25}$

Our study results indicate poor awareness and wrong practice pattern toward antibiotic use among Saudi people which is consistent with many studies in KSA revealed a poor knowledge and wrong practice pattern among most of the Saudi subjects. In Riyadh, about $77.6 \%(p<0.05)$ of adult subjects would buy antibiotics without prescriptions. ${ }^{26} \mathrm{Also}$, a high incidence of antibiotic misuse was found among $38.7 \%$ of pediatric and $57.8 \%$ of adult emergency department at the King Abdullah international medical research center. ${ }^{27}$ In addition, the antibiotic misuse was associated with a high rate of infection in a community hospital in $\mathrm{KSA}^{28}$
Self-medication is associated with little guidance regarding appropriate antibiotic selection for individual symptoms and safe practices to minimize adverse effects even when provided by a pharmacist. ${ }^{29,30}$ In our study, the majority of respondents who self-medicate identified pharmacists in private pharmacy as the main source of information. The potential for adverse events is known. Generally, pharmacy staff didn't inquire about patient's allergies, didn't explain potential side effects and also predispose the patient to drug interactions, super infection and also administration of antibiotic which is not suitable for diagnosis lead to higher bacterial resistance. ${ }^{31}$

\section{CONCLUSION}

Our community still has some misconceptions and insufficient knowledge regarding antibiotic resistance. There is great concern surrounding the development and spread of resistance resulting from poor knowledge about the dangers of self-medication and misuse of antibiotics. Poor knowledge and attitude toward antibiotic use in Saudi community must be corrected. Raising public and medical awareness of AMR is an important element that is urgently needed to tackle AMR in Saudi Arabia. Health education on antimicrobial resistance at all levels is imperative, which can be achieved through health educational campaigns to educate the population regarding the usage of antibiotics and the complications of the misuses and what are the indications of antibiotics to improving the antimicrobial use and to correct false beliefs about antibiotics. Multilevel and nationwide campaign in Saudi Arabia is needed to align with the world antibiotic awareness week. The success of the campaign can be dependent on the tailored and relevant content and key messages that are designed after formative research. The increasing use of social media platform in the country can help to disseminate awareness messages. Large scale future studies are needed to measure 
the extent of antibiotic misuse problem in different populations to help authorities to undertake the required action.

\section{ACKNOWLEDGEMENT}

The authors would like to convey their heartiest gratitude to Dr. Mohammad Daud Ali, for providing timely support and suggestions related to statistical analysis of data.

\section{ABBREVIATIONS}

AMR: Antimicrobial Resistance; MDR: Multidrug Resistant; URTIs: Upper Respiratory Tract Infections; KSA: Kingdom of Saudi Arabia

\section{REFERENCES}

1. Harbarth S, Balkhy $H H$, Goossens $H$, Jarlier V, Kluytmans J, Laxminarayan $R$ et al. Antimicrobial resistance: one world, one fight. Antimicrob Resist Infect Control. 2015;4:49.

2. Zowawi HM, Harris PN, Roberts MJ, Tambyah PA, Schembri MA, Pezzani MD, et al. The emerging threat of multi drug resistant Gram-negative bacteria in urology. Nat Rev Urol. 2015;12:570-84.

3. Laxminarayan R. Antibiotic effectiveness: Balancing conservation against innovation. Science. 2014;345(6202):1299-301.

4. Morgan DJ, Okeke IN, Laxminarayan R, Perencevich EN, Weisenberg S. Nonprescription antimicrobial use worldwide: A systematic review. Lancet Infect Dis. 2011;11(9):692-701.

5. Zowawi HM, Forde BM, Alfaresi M, Alzarouni A, Farahat Y, Chong TM, et al. Stepwise evolution of pandrug-resistance in Klebsiella pneumoniae. Sci Rep. 2015;5:15082.

6. World Health Organization. Antibiotic Resistance: Multi-Country Public Awareness Survey. Oslo, Norway: WHO. http://www.who.int/drugresistance/ documents/baselinesurveynov2015/en/

7. Shehadeh M, Suaifan G, Darwish RM, Wazaify M, Zaru L, Alja'fari S. Knowledge, attitudes and behavior regarding antibiotics use and misuse among adults in the community of Jordan: A pilot study. Saudi Pharm J. 2012;20(2):125-33.

8. Carl L, María JM, Guillermo G, Javier A, Josep MC, Lars B. Interventions to improve adherence to first-line antibiotics in respiratory tract infections: The impact depends on the intensity of the intervention. Eur J Gen Pract. 2015;21(1):12-8.

9. Mohanna M. Self-medication with antibiotic in children in Sana'a city, Yemen. Oman Med J. 2010;25(1):41-3

10. Napolitano F, Izzo MT, Di Giuseppe G, Angelillo IF. Public knowledge, attitudes and experience regarding the use of antibiotics in Italy. PloS One. 2013;8(12):e84177.

11. McNulty CA, Boyle P, Nichols T, Clappison P, Davey P. The public's attitudes to and compliance with antibiotics. J Antimicrob Chemother. 2007;60(1):63-8.

12. Thriemer K. Antibiotic prescribing in DR Congo: A knowledge, attitude and practice survey. PLoS One. 2013; 8(2):e55495.

13. Sellman JS, Decarolis D, Schullo-Feulner A, Nelson DB, Filice GA. Information resources used in antimicrobial prescribing. J Am Med Inform Assoc. $2004 ; 11(4): 281-4$.
14. Khan A, Banu G, Reshma KK. Antibiotic resistance and usage: A survey on the knowledge, attitude, perceptions and practices among the medical students of a southern Indian Teaching Hospital. J Clin Diag Res. 2013;7(8):1613-6.

15. Khan AKA, Banu G, Reshma KK. Antibiotic Resistance and Usage-A Survey on the Knowledge, Attitude, Perceptions and Practices among the Medical Students of a Southern Indian Teaching Hospital. J Clin Diagn Res. 2013;7(8):1613-6.

16. Azevedo MM, Pinheiro C, Yaphe J, Baltazar F. Portuguese students' knowledge of antibiotics: A cross-sectional study of secondary school and university students in Braga. BMC Public Health. 2009; 9:359.

17. Steinberg I. Clinical choices of antibiotics: Judging judicious use. Am J Manag Care. 2000; 6(23):S1178-88.

18. Belkina T, AlWarafi A, Eltom EH, Tadjieva N, Kubena A, Vlcek J. Antibiotic use and knowledge in the community of Yemen, Saudi Arabia and Uzbekistan. J Infect Dev Ctries. 2014;8(4):424-9.

19. Dooling KL, Kandeel A, Hicks LA, El-Shoubary W, Fawzi $K$, Kandeel $Y$, et al. Understanding antibiotic use in Minya District, Egypt: Physician and pharmacist prescribing and the factors influencing their practices. Antibiotics. 2014;3(2):233-43.

20. Al-Ramahi R. Patterns and attitudes of self-medication practices and possible role of community pharmacists in Palestine. Int J Clin Pharmacol Ther. 2013; 51(7):562-7.

21. Muras M, Krajewski J, Nocun M, Godycki-Cwirko M. A survey of patient behaviors and beliefs regarding antibiotic self-medication for respiratory tract infections in Poland. Arch Med Sci. 2013;9(5):854-7.

22. Shet A, Sundaresan S, Forsberg BC. Pharmacy-based dispensing of antimicrobial agents without prescription in India: Appropriateness and cost burden in the private sector. Antimicrob Resist Infect Control. 2015;4(1):1.

23. Ramay $B M$, Lambour $P$, Ceron $A$. Comparing antibiotic self-medication in two socio-economic groups in Guatemala City: A descriptive cross-sectional study. BMC Pharmacol Toxicol. 2015;16(1):11.

24. Belkina T, AlWarafi A, Hussein EE, Tadjieva N, Kubena A, Vlcek J. Antibiotic use and knowledge in the community of Yemen, Saudi Arabia and Uzbekistan. J Infect Dev Ctries. 2014;8:424-9.

25. Bin AAA, Altannir MA, Almansor MA, Almohaya MS, Onazi AS, Marei MA, et al. Non prescribed sale of antibiotics in Riyadh, Saudi Arabia: A Cross Sectional Study. BMC Public Health. 2011;11:538.

26. Alanazi MQ, Al-Jeraisy MI, Salam M. Prevalence and predictors of antibiotic prescription errors in an emergency department, Central Saudi Arabia. Drug Healthc Patient Saf. 2015;7:103-11.

27. Al-Ghamdi S, Gedebou M, Bilal NE. Nosocomial infections and misuse of antibiotics in a provincial community hospital, Saudi Arabia. J Hosp Infect. 2002; 50(2):115-21.

28. Llor C, Cots JM. The sale of antibiotics without prescription in pharmacies in Catalonia, Spain. Clin Infect Dis. 2009;48(10):1345-9.

29. Grigoryan L, Haaijer-Ryskamp FM, Burgerhof JG, et al. Self-medication with antimicrobial drugs in Europe. Emerg Infect Dis. 2006;12(3):452-9.

30. Chalker J, Ratanawijitrasin S, Chuc NT, Petzold M, Tomson G. Effectiveness of a multicomponent intervention on dispensing practices at private pharmacies in Vietnam and Thailand-a randomized controlled trial. Soc Sci Med. 2005;60(1):131-41.

31. Morgan DJ, Okeke IN, Laxminarayan R, Perencevich EN, Weisenberg S Nonprescription antimicrobial use worldwide: A systematic review. Lancet Infect Dis. 2011;11(9):692-701.

Article History: Submission Date: 05-03-2020; Revised Date: 02-05-2020; Acceptance Date: 21-06-2020

Cite this article: Alenazi AAH, Alotaibi NM, Muitaba MA. A Survey of Public Knowledge and Attitude Related to Antibiotic use and Antibiotic Resistanceamong Saudi People in Northern Region of Saudi Arabia. J Young Pharm. 2020;12(3):237-41. 